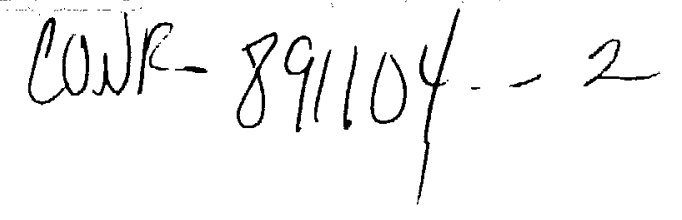

\title{
RADON LEVELS INSIDE RESIDENCES IN MEXICO CITY
}

\author{
G. Espinoza \\ Institute of Physics \\ National University of Mexico \\ Mexico City, Mexico \\ and \\ R. B. Gammage* \\ Oak Ridge National Laboratory \\ Health and Safety Research Division \\ Oak Ridge, Tennessee 37831-6383
}

CONF-891104--2

DE90 004934

\section{ABSTRACT}

Levels of radon were measured during winter and spring seasons inside 55 colonial and modern houses and 30 multifamily apartment buildings representative of middle and upper income families. The modern houses and apartment buildings in the southern section of the city had average radon levels exceeding $150 \mathrm{~Bq} \mathrm{~m} \mathrm{~m}^{-3}$ with a maximum single measurement of $458 \mathrm{~Bq} \mathrm{~m}^{-3}$. The colonial houses in the central downtown section had radon levels nearly all averaging below 100 $\mathrm{Bq} \mathrm{m}^{-3}$ Between the ground and third floor of the apartment buildings, radon levels diminished by tenfold indicating that entry of radon-bearing soil gas was largely responsible for the elevated concentrations of radon. The radon levels in winter exceeded by about $30 \%$ the radon levels during spring. The potentially adverse health effects of these radon levels may be exacerbated by the quality of air in Mexico City which during winter is often highly polluted.

${ }^{*}$ Research sponsored by U. S. Department of Energy under contract DE-AC05-84OR21400 with Martin Marietta Energy Systems, Inc.
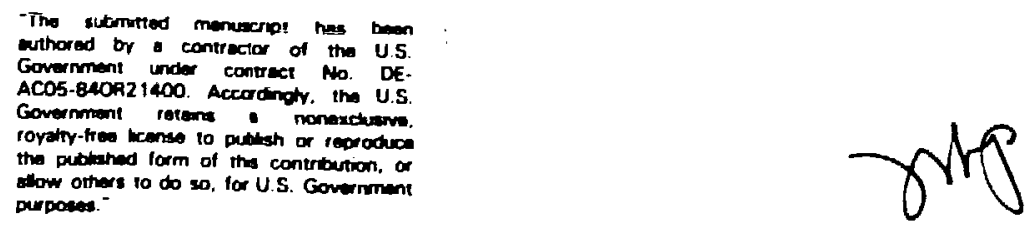


\section{INTRODUCT"ON}

Indoor exposures to radon have received considerable attention in European ' ountries and in the U.S. The latter country recently established the goal of reducing indoor radon levels to outdoor ambient levels (1) reflecting concern that radon is perhaps the greatest environmental cancer threat to the general population. There have also been extensive measurements to establish geographical patterns of indoor radon levels in deveioped countries (2). In developing countries, such as Mexico, there have been more meager attempts to define indoor radon problems. The currently reported study is a modest attempt to rectify this deficiency in the Mexican capital where about one quarter of the nation's populace resides.

\section{RADON MEASUREMENTS}

Nuclear track detectors composed of CR-39. (Pershore Molding Ltd., England) were used to measure integrated exposures to radon. The pretreatment, etching, and counting procedures have been described (3).

One detector at a time was placed in a room where a radon measurement was being made. The detector was exposed for one month and then immediately replaced with a new detector. Measurements were made during the winter and spring seasons. In each residence, measurements were made in the living room, dining room and bedroom closest to ground level. Multiple detector measurements were made at single locations; the measurement precision was $\pm 20 \%$ at radon concentrations in excess of $100 \mathrm{~Bq} \mathrm{m^{-3 }}$. 


\section{RESIDENCES}

Three types of residences were studied. Twenty-five single family homb.; were older colonial-style houses situated in the central zone of the city. Thirty single family homes were of contemporary style. built on hillsides in the southern section of Mexico City. Thirty apartments were in multifamily, multistory buildings, located south of the city center.

\section{RESULTS AND DISCUSSION}

The indoor measurements of radon in single and multifamily dwellings are tabulated in Tables 1 and 2, respectively. There are several salient features. In the southern sections of Mexico City, the average wintertime levels of radon range between 175 and $348 \mathrm{~Bq} \mathrm{~m}$. These levels of radon were found in both modern houses and in apartment buildings at the ground level. The U.S. Environmental Protection Agency recommends considering remedial action within a few years if radon levels are between $150 \mathrm{~Bq} \mathrm{~m} \mathrm{~m}^{-3}(4 \mathrm{pCi} / \mathrm{L})$ and $740 \mathrm{~Bq} \mathrm{~m}^{-3}(20 \mathrm{pCi} / \mathrm{L})(4)$. If the radon leve's are higher then remedial action is recommended within months, or even weeks if measurements reveal $7400 \mathrm{~Bq} \mathrm{~m}$ or higher. In Mexico, the federal agencies have yet to establish similar guidelines. In fact the present study is the first moderately extensive attempt to evaluate existing residential radon problems in Mexico City.

The radon levels in colonial-type residences in the central section of the city averaged well below $150 \mathrm{~Bq} \mathrm{~m} \mathrm{~m}^{-3}$. The highest single measurenent was $156 \mathrm{~Bq} \mathrm{~m}^{-3}$. The lower radon levels in the lower lying central zone probably reflect the lakebed origin of the underlying soil; either the radium content of lakebed sediment is less than that in the higher, rockier ground of the southern sections 
or the soil permeability is lower. The current study involves only 55 out of the more than 2.5 million buildings in Mexico. The study does no more, therefore, than point to radon problems of moderate significance existing in regions elevated above the old lakebed section of Mexico City. Taking the single highest seasonal reading in each of the tota! 55 residences, $45 \%$ of these residences exceeded $150 \mathrm{~Bq} \mathrm{~m}$. If such an evaluation is restricted to residences in the southern sections of the city, then the percentage rises to $60 \%$.

The measurements of radon in the multifamily apartment buildings were made on the ground, first, second, and third floors. The radon concentration was distinctly greater at the ground level. There are decrements in radon concentration of about $50 \%$ between successively higher Bloors. This trend indicates that the principal source of indoor radon is likely to be soil gas entering the building at ground level. The importance of pressure-driven flow of air through soil and into buildings has been well established by $U$. S. investigators $(5,6)$. A secondary source of indoor radon is associated with the natural radioactivity of the bricks, concrete and gravel used in construction of houses in Mexico City (3). Stone and stone products are used extensively in their construction. Most of these items are made with materials excavated locally.

The average levels of radon are approximately $30 \%$ higher in winter compared to the spring. The indoor "thermal stack effect" (7) is usually invoked to explain higher radon levels during wintertime in colder climates. The winter in Mexico City remains relatively mild and the custom is to use indoor heating only irregularly, or not all. The indoor "thermal stack effect" may not be underlying reason for the higher wintertime radon levels; rather, the stagnant, windless atmospheric conditions typical of the winter scason in Mexico City may be contributing to pe si ventilation and allowing accumulation of radon. All houses in the study rely on natural ventiation. 
There is marked buildup of urban atmospheric pollutants during temperat t. ic inversions affecting Meaco City in the wintertime. The potential for synergism between dirty city air and elevated indoor radon levels in increasing risk of lung cancer only adds to the need for more thoroughly evaluating radon levels in Mexico City in the future.

\section{CONCLUSION}

Indoor radon levels have been measured in 55 residences within Mexico City using integrating track etch detectors. Significant levels of radon (>150 Bq m m $^{-3}$ ) were found inside buildings away from the center of the city with levels higher during winter than spring. Expanded studies are needed to determine the extent and severity of radon problems in other sections of the Federal District, as well as in the 31 other states of Mexico.

\section{DISCLAIMER}

This report was prepared as an account of work sponsored by an agency of the United States Government. Neither the United States Government nor any agency thereof, nor any of their employees, makes any warranty, express or implied, or assumes any legal liability or responsibility for the accuracy, completeness, or usefulness of any information, apparatus, product, or process disciosed, or represents that its use would not infringe privately owned rights. Reference herein to any specific commercial product, process, or service by trade name, trademark, manufacturer, or otherwise does not necessarily constitute or imply its endorsement, recommendation, or favoring by the United States Government or any agency thereof. The views and opinions of authors expressed herein do not necessarily state or reflect those of the United States Government or any agency thereof. 


\section{REFERENCES}

1. Amendment of Toxic Substances Control Act, Title III-Indoor Radon Abatement, Section 301, National Goal. Congressional Record-Senate, S15259, October 7, 1988.

2. Nero, A. V., Schwehr, B. M., Nazaroff, W. W., and Revzan, K. L. Distribution of airborne Radon-222 concentrations in U. S. homes, Science 234, $992-997$ (1986).

3. Espinoza, G., Golzarri, J. I., Gamboa, I., and Iacobson, I. Natural radioactivity in Mexican building material by SSNTD. Nuci. Tracks $12,767-770$ (1986).

4. U. S. Environmental Protection Agency. A Citizen's Guide to Radon. Washington, DC: U. S. Government Printing Office; EPA-86-004, 1986.

5. Nazaroff, W. W., Lewis, S. R., Doyle, S. M., Moed, B. A. and Nero, A. V. Experiments on pollutant transport from soil into residential basements by pressure-driven airflow, Environ. Sci. and Technol., 21, 459-466 (1987).

6. Nason, R. and Cohen, B. L. Correlation between ${ }^{226} R a$ in soil, ${ }^{222} R n$ in soil gas, and ${ }^{222} R n$ inside adjacent houses. Health Phys. 52 73-77 (1987). 
7. Nero, A. V., Sextro, R. G., Doyle, S. M., Moed B. A., Nazaroff, W. W., Revzan, S. S., and Schwehr, M. B. Characterizing the sources and range of environmental influences of Radon222 and its decay products. Sci. Total Environ. 45, 233-244 (1985). 
Table 1. Levels of Radon ( $\mathrm{Bq} \mathrm{m} \mathrm{m}^{-3}$ ) in Single Family Residences

\begin{tabular}{|c|c|c|c|c|c|c|}
\hline \multirow[b]{2}{*}{ House Type/Room } & \multicolumn{2}{|c|}{ Minimum } & \multicolumn{2}{|c|}{ Maximum } & \multicolumn{2}{|c|}{ Average } \\
\hline & Winter & Spring & Winter & Spring & Winter & Spring \\
\hline Colonial/Living & 18 & 15 & 83 & 58 & 62 & 49 \\
\hline Colonial/Dining & 18 & 15 & 97 & 63 & 75 & 52 \\
\hline Colonial/Bedroom & 35 & 21 & 156 & 112 & 107 & 89 \\
\hline Modern/Living & 83 & 77 & 275 & 210 & 180 & 127 \\
\hline Modern/Dining & 71 & 77 & 260 & 210 & 163 & 127 \\
\hline Modern/Bedroom & 210 & 160 & 458 & 356 & 348 & 272 \\
\hline
\end{tabular}


Table 2. Levels of Radon ( $\mathrm{Bq} \mathrm{m}^{-3}$ ) in Multifamily Apartment Buildings

\begin{tabular}{|c|c|c|c|c|c|c|}
\hline \multirow[b]{2}{*}{ Floor/Ruom } & \multicolumn{2}{|c|}{ Minimum } & \multicolumn{2}{|c|}{ Maximum } & \multicolumn{2}{|c|}{. Average } \\
\hline & Winter & Spring & Winter & Spring & Winter & Spring \\
\hline Ground/Living & 125 & 91 & 337 & 210 & 225 & 187 \\
\hline Ground/Dining & 125 & 91 & 352 & 210 & 232 & 187 \\
\hline Ground/Bedroom & 122 & 72 & 214 & 152 & 175 & 110 \\
\hline First/Living & 63 & 43 & 120 & 91 & 98 & 70 \\
\hline First/Dining & 60 & 40 & 120 & 97 & 93 & 72 \\
\hline First/Bedroom & 48 & 26 & 79 & 57 & 65 & 48 \\
\hline Second/Living & 22 & 16 & 59 & 46 & 47 & 32 \\
\hline Second/Dining & 20 & 15 & 60 & 46 & 48 & 32 \\
\hline Second/Bedroom & 12 & 11 & 29 & 18 & 23 & 15 \\
\hline Third/Living & 15 & 12 & 27 & 20 & 21 & 18 \\
\hline Third/Dining & 15 & 10 & 29 & 21 & 22 & 17 \\
\hline Third/Bedroom & 9 & 4 & 17 & 15 & 13 & 10 \\
\hline
\end{tabular}

